\title{
Development Through Good Governance
}

Ass. Prof. Dr. Nada Krypa (Tapija)

Lecturer of Business Management Vice Dean of Economic Faculty,

"Aleksander Xhuvani” University, Albania

nadakrypa@yahoo.com,nada.tapija@uniel.edu.al

\begin{abstract}
Since the 1990s the concept 'good governance' has become one of the most widely used in debates in development, public policy and international relations. Despite its recent prominence the concept 'good governance' has frequently used in different meanings and implications. Following an introduction, which includes a historiographic note on development discourse, the first part of this paper is intended to be an overview of diverse definitions, interpretations and measuring problems of good governance. The purport of the second part of this paper is to focus on whether good governance matters in development or not, the performance of good governance in Albania. This paper has argued that good governance is indispensable in Albania, because misgovernance is a great hindrance and predicament to development. The politicization of bureaucracy, judiciary, appointment, transfer and promotion in all most all offices, lack of voice and accountability, inefficiency and satisfying the vested interest fall within the purview of misgovernance.
\end{abstract}

Keywords: good governance, development, international relations, Albania

"Good governance is perhaps the single most important factor in eradicating poverty and promoting development. "

\section{Kofi Annan, Secretary General of the United Nations ${ }^{1}$}

\section{Introduction}

Development is a global phenomenon. The earliest modern theory of development had emerged at the end of the Second World War. President Harry S. Truman's Inaugural Address on 20 January 1949 was very important internationally to the formation of this new paradigm of development. The Western ideology of development assuming that the problems of

${ }^{1} \mathrm{~K}$ Annan 'Annual report of the Secretary-General on the Work of the Organization' A/53/1 27 August 1998.

Available at http://www.un.org/Docs/SG/Report98/con98.htm (accessed 31 October 2008) 
underdeveloped countries such as poverty, inadequate social services and low levels of industrial production were amenable by the application of superior Western technology, institutions, modes of production and values. But in a short time the achievement of development goals had proved elusive, and a major part of the world had experienced poverty, indebtness, political repression, economic stagnation etc.

The concept of governance ${ }^{1}$ has gained a lot of prominence since the decolonisation process began with the formation of the United Nations (UN) in 1945. After its formation, the UN was faced with the challenges of decolonisation of territories and the granting of self 'governance' or independence to territories. Debates on governance resurfaced again in the early 1990s with political and economic dimensions especially with the failure of SAP. The precise meaning of governance is still subject to many debates both in content, parameters and structure. ${ }^{2}$ According to Weiss, these conflicts of perceptions are due to the ever changing nature of governance, the emergence of diverse global, regional and national frameworks on governance and the increasing interrelatedness of governance to other themes such as economic and social development. 3

The idea of good governance has always occupied the discussions of public administrators, civil society and the development as well as aid communities. In its traditional sense, good governance is usually used with particular reference to political governance. In this guise, it is related to such concepts as democracy, participation, human rights, rule of law and transparency, amongst others. Good governance ensures that political authorities and institutions are accountable to the guarantee of all human rights becauseall rights are universal, interdependent, interrelated and indivisible as enunciated by the Vienna Declaration. ${ }^{4}$ The advent of globalisation and the integration of global economies have further extended the concept of good governance to the efficient management of resources to inspire economic growth and development.

The idea of corporate governance was quickly adopted in different parts of the world but with some major variations because circumstances vary from country to country. Consequently, a variety of corporate governance frameworks were developed. Nevertheless, two main approaches of corporate governance can be identified, with distinctions arising from the different legal systems at work in different countries. Countries that followed civil law (e. g. France, Germany, Italy) developed corporate governance frameworks that focused on stakeholders. In those countries, the role of corporate governance was to balance the interests of a variety of key groups such as employees, managers, creditors, suppliers, customers and the wider community. On the other hand, countries that had a tradition of common law (e. g. Australia, United Kingdom, USA, Canada) developed corporate governance structures that focussed on shareholders' returns or interests.

In this paper, we will try to explore: (a) diverse definitions and interpretations of the concept of good governance; (b) measuring problems of good governance; (c) does good governance matter in development? (d) good governance and development (e) the performance of good governance in Albania.

\subsection{GOVERNANCE: A journey through definitions}

The term 'good governance' is a relatively recent fashion. As it is mentioned earlier, it has emerged from virtual obscurity in the last decade of the twentieth century, and takes a central place in the development discourse, carrying the thought that it is 'good governance' that leads to development. In general terms, 'good governance' means developing institutions and processes that are more responsive to the ordinary citizens, including the poor. It implies the promotion of participation, accountability and effectiveness at all levels. Practicians, development workers and international development agencies have taken up the concept as a new way of thinking about public sector, political and administrative structures of developing countries. The IMF5, World Bank and United Nations have taken an extensive campaign for promoting good governance

\footnotetext{
1 Francis $(2000)$

2 U Simonis (ed.) 'Defining good governance: The conceptual competition is on' (2004) Wissenschaftszentrum Berlin für Sozialforschung (WZB) 3-4.

${ }^{3}$ T Weiss 'Governance, good governance and global governance: Conceptual and actual challenges' (2000) 21 Third World Quarterly 795-796.

${ }^{4}$ Adopted by 171 countries participating in the World Conference on Human Rights, held in Vienna from 14 - 25 June1993.

5 The International Monetary Fund
} 
as the new reform objective in the Third world. There have also been some thematic approaches to the definition of governance. Some of these are outlined below:

From an economic perspective, the World Bank sees governance as: "Concerned with the management of the development process, involving both the public and private sectors. It encompasses the functioning and capability of the public sector, as well as the rules and institutions that create the framework for the conduct of both public and private business, including accountability for economic and finance performance, and regulatory frameworks relating to companies, corporations and partnerships. "Administratively, the UNDP opines that: "Governance can be seen as the exercise of economic, political and administrative authority to manage a country's affairs at all levels. It comprises the mechanisms, processes and institutions, through which citizens and groups articulate their interest, exercise their legal rights, meet their obligations and mediate their differences. "2

Marie Besancon defines governance as the delivery of political goods, beginning with security -to the citizens of nationstates. Good governance then according to her, results when nationstates provide a high order of certain political goods; when the nation states perform effectively and well on behalf of their citizens ${ }^{3}$. The International Monetary Fund (IMF) emphasize the importance of sound macroeconomic policies and the fight against corruption, while some bilateral donors and non-governmental organizations (NGOs) put more stress on democratization and human rights. Organization for Economic Cooperation and Development (OECD) on the other hand limits 'good governance' clearly only to the level of public sector, stating, "Good governance is established when public institutions act efficiently, providing an enabling environment for economic growth and development.

\section{2 Understanding Good Governance}

The concept of good governance has emerged as an important element of discourse in matters of development. Issues of good governance are increasingly taking the centre stage in development discourse at local and global levels. On the international scene, commitment to good governance is now seen as key to the achievement of development objectives. Good governance has also formed a major part of the commitment of nations to foster sustainable growth and human development in their respective societies. Good governance from a human rights perspective is linked to an enabling environment conducive for the enjoyment of human rights and promoting growth and human development. It has also been described as governing "in a manner essentially free of abuse and corruption, and with due regard to the rule of law."

Adding his voice to this perspective, the former Kofi Annan, defined good governance as ensuring respect for human rights and the rule of law, strengthening democracy, and promoting transparency and capacity in public administration. ${ }^{4}$ Good governance from an economic point of view "concerns norms of behaviour that help ensure that governments actually deliver to their citizens what they said they will deliver. "Good governance in this sense is important in the transparent and disciplined management of resources, the design and implementation of economic policies for pro-poor growth and human development. These conditions range from institutional to legal mechanisms entrenching the following: (a) Public participation in the process of governance;(b) Accountability and transparency on the part of government and its institutions; (c) Respect for the rule of law and human rights; (d) Efficient and effective public sector management.

\section{3 Measuring Problems of Good Governance}

Measuring good governance is a complicated issue due to the absence of it's among its proponents, but of course it is not impossible. Simply, governance, as mentioned earlier, was defined as nation states delivering certain political goods to its citizens. Good governance is always performance oriented. As these political goods refer to the nation state providing concrete lists of goods like democracy, health care, rule of law etc., it should be possible to measure the extent to which the nation states are doing or failing in doing their governing i. e. delivering these political goods. Once it is possible to

\footnotetext{
1 World Bank Managing development: The governance dimension (1991) 1; See also OECD Participatory Development and Good Governance (1995) 14. Available at http://www.oecd.org/dataoecd/27/13/31857685.pdf (accessed 15 October 2008).

2 UNDP Reconceptualising Governance (1997).

3 Besancon 2003:1.

${ }^{4}$ Weiss (n 26 above) 797, 801-5.
} 
measure governance, it is also possible to analyze the impact of other variables on governance, what role does governance in development, economic growth?

Different methodologies and tools have been developed to measure good governance, depending on the purpose of measurement, for example, to analyze the overall situation or general trends within a country, to determine the degree to which a specific government is respecting its obligations in principle, or to determine the practical situation on the ground. We identified five types of measures of good governance, including: (1) civil and political liberties or political freedoms as proxy measures for the rule of law, (2) the frequency of political violence as an inverse measure of good governance, (3) expert assessments and opinion of good governance for investment, (4) objective indicators such as 'contract intensive money' as a measure of individual confidence in the domestic financial institutions or the 'economic rate of return' of governmental projects, and (5) mixed measures economic modernization. Each of the mentioned initiative however has its own strengths and weaknesses.

\section{GOOD GOVERNANCE AND DEVELOPMENT}

From the above discussions on the meanings, concepts and elements of governance and good governance, it becomes imperative to explore the role good governance plays in the development process. This is underscored by the fact that since governance is all about managing institutions, systems, processes and complex relationships; it invariably could impact in a lot of ways on the ends of development. Apart from impacting on social and political progress through the creation of environments to foster interests and social well being, governance also impacts on economic growth and human development. This is seen from the manner in which government exercises control and manages human and material resources as well as provide social services and infrastructure.

Does Good Governance Matter in Development? Currently, as it is noted earlier, the international multilateral agencies have profoundly been given importance on good governance in the developing countries. According to donors good governance is closely associated with economic development.

\section{1 Good Governance -Positive contribution to development}

Various developing countries which are quite comparable in terms of their natural resources (land, water, arable soil, minerals, climate etc. ) and social structures have over the past thirty years shown strikingly differing records of economic and social progress. Measured by the criteria of child mortality, life expectancy and literacy, the key indicators of quality of life, some countries have made considerably greater progress than others, even though they all operate in the same world economic environment and have comparable colonial pasts.

In light of this fact, coupled with the uneasiness caused by irresponsible rulers in a number of countries, the matter of "governance" has come to the forefront of the debate over development policy. "Governance" is the art of public leadership. There are three distinct dimensions of governance: (1) the form of political regime; (2) the process by which authority is exercised in the management of a country's economic and social resources; and (3) the capacity of governments to design, formulate, and implement policies and discharge functions. The criteria that constitute good governance have been drawn from these three dimensions, and include:

legitimacy of government (degree of "democratization"),

accountability of political and official elements of government (media freedom, transparency of decision-making, accountability mechanisms),

competence of governments to formulate policies and deliver services,

respect for human rights and rule of law (individual and group rights and security, framework for economic and social activity, participation). 
"Good governance" puts people into the center of development. "Where people grow, profits grow": this well-tried business rule is applicable to development policy as well.

\section{PERFORMANCE OF GOOD GOVERNANCE IN ALBANIA}

In the past two decades, the Albanian state and its society have witnessed a relatively long transition period from 50 years of a communist totalitarianism towards a democratic free market economic regime. Among other things, the transition period featured major changes of the country's geopolitical diplomatic relationships with the rest of the world, where European Union (EU) integration goals replaced isolation and xenophobic policy. In addition to positive developments, the Albanian transition has been also associated with negative phenomena like high and persistent unemployment, corruption, weak domestic institutions and partially free markets. Despite the country's progress in many areas, progression towards EU integration goals is very slow.

In a broad sense, it is clear that governance quality in Albania has proved good enough to enable (or, in some areas, bring about) improved development outcomes. It could be argued that, given its highly disadvantageous starting conditions following the 1997 crisis, Albania has exceeded expectations in economic performance and governance. Extensive research points to a correlation between a country's quality of governance and its level of economic development. It would thus be unrealistic to expect Albania, a middle-income country with young state institutions and a recent history of tremendous political, economic, and social transformation, to match the quality of governance of higherincome countries with well-established institutions.

European Union is one of the most important drivers of change. Albanian government has identified EU membership as its key policy objective and therefore has started the implementation of the required reforms in the areas of public administration and rule of law in particular. The most recent development has been visa liberalization approved by the European Parliament (2010), which was a result of EU's recognition of Albania's advancements in the strengthening of law enforcement capacities, implementation of the legal framework in the area of the confiscation of organized crime assets in particular. European Union has identified Public Administration's legal framework and civil service system to be mostly in line with the European standards and practice.

International Community, Media and the general public are also important actors, which together with the EU should play an increasingly significant role in the future. Due to the high state capture and administrative corruption in Albania, reforms should first of all be directed towards changing the incentive structure of the political leadership. Costs of state capture should be increased and gains available from controlling the state reduced. Since leadership is part of the problem, the International Community should play an active role in supporting the implementation of proper anti-corruption policies, which should be developed through a transparent political dialogue involving an active participation by the civil society.

Media is an important actor in facilitating this process. It should continue uncovering corruption scandals and discussing the meaning of corruption, which in some cases, such as paying a bribe to a doctor to receive treatment even though healthcare in Albania is a public good, has become a norm. It is very important that the international community supports the establishment of independent media channels. Since Albania doesn't have an extensive democratic history, the public still needs to discover its rights. When voters learn to hold representatives accountable for their actions, the demand for proper governance policy oriented politicians will emerge.

\section{CONCLUSION}

Good governance agenda is an emerging priority for the international community. It can be considered more pragmatic for meeting the public demands, promoting efficiency and development of a country. Although some observers, policy makers and administrators question these new interest by international organizations, stating that an unacceptable attempt to impose 'Western values not being compatible with our culture'. But we think that good governance is very important in the context of Albania. In this paper $i$ argued that good governance is indispensable in Albania, because misgovernance is a great hindrance and predicament to development. 
The politicization of bureaucracy, judiciary, appointment, transfer and promotion in all most all offices, lack of voice and accountability, inefficiency and satisfying the vested interest fall within the purview of misgovernance. Because misgovernance is evident in every sphere of our national life. Without improving the key indicators of good governance, like rule of law, voice and democratic accountability, stable political regimes, government effectiveness and control of corruption it is not possible to achieve rapid per capita income and improve other social indicators. A modest growth in income cannot guarantee better rule of law or improved voice and accountability.

Misgovernance has serious implications such as unattainability of growth path, suffering of pro poor strategies, lack of foreign investment, unstable political regimes etc. Good governance may extremely complex but it is essential for curbing corruption, reducing poverty and to ensure a dynamic economy and development. For achieving good governance, on the one hand, we need strong accountable and effective political institutions, patriotism and, on the other hand, aid agencies such as, IMF, UNDP, World Bank etc. should have a long-term commitment of funds and expertise to support governance reform projects.

\section{REFERENCES}

[1] Albania Progress Report 2011\{COM(2011)666)

[2] Bank of Albania (2010), (2011), "Corporate Governance in Albania"

[3] Besancon, Marie (2003, "Good Governance Rankings: The Art of Measurement” WPF Reports

[4] Hirst, Paul (2000), 'Democracy and Governance' in Pierre, Jon (ed. ),Debating Governance- Authority, Steering and Democracy, Oxford: Oxford University Press. p. 14

[5] International Monetary Fund (2011), Country Report No. 11/31

[6] Kaufmann. D, A. Kraay, M. Mastruzzi (2003). Governance Matters

[7] Keefer, Philip and Stephen, Knack (1995). "Institutions and Economic Performance: Cross- Country Test Using Alternative Institutional Measurs", Economic and Politics, 7: 207-227.

[8] Landman, T and J. Hauserman (2003), Map-Making and Analysis of the Main International Initiatives on Developing Indicators on Democracy and Good Governance, University of Essex, Human Rights Centre.

[9] Mauro, Paolo (1998), "Corruption and the Composition of Government Expenditure", Journal of Public Economics, 69:263-279.

[10] Myrdal, Gunnar (1970), The Challenge of World Poverty. Penguin. P. 239.

[11] Santiso, C. (2001), "Good Governance and Aid Effectiveness: The WorldBank and Conditionality", The Georgetown Public Policy Review, Vol. 7, No. 1, pp. 1-23.

[12] Tanzi, Vito and Hamid Davoodi (1997), ' Corruption, Public Investment and Growth', IMF Working Paper, Washington DC: International Monetary Fund, October 